\title{
Thermal volume changes and creep in the Callovo-Oxfordian claystone.
}

\author{
Malik Belmokhtar ${ }^{l}$, Pierre Delage ${ }^{l}$, Siavash Ghabezloo ${ }^{1}$, Nathalie Conil ${ }^{2}$ \\ ${ }^{1}$ Ecole des Ponts ParisTech, Laboratoire Navier/CERMES, 6-8 av. B. Pascal, F77455 Marne la Vallée, France \\ ${ }^{2}$ Andra, Bure, France
}

\section{Abstract}

The Callovo-Oxfordian (COx) claystone is considered as a potential host rock for high-level radioactive waste disposal at great depth in France. Given the exothermic nature of radioactive wastes, a temperature elevation planned to be smaller than $100^{\circ} \mathrm{C}$ will affect the host rock around the disposal cells. To gain better understanding of the thermal volumetric response of the COx claystone, a new thermal isotropic compression cell was developed with particular attention devoted to monitoring axial and radial strains. To do so, a high precision LVDTs system ensuring direct contact between the LVDT stem and the claystone sample through the membrane was developed. A short drainage length $(10 \mathrm{~mm})$ was also ensured so as to allow full saturation of the sample under stress conditions close to in-situ, and fully drained conditions during compression. High precision strain monitoring allowed to observe a volumetric creep under stress conditions close to in-situ. A drained heating test under constant stress carried out afterwards up to $80^{\circ} \mathrm{C}$ exhibited a thermo-elastic expansion up to a temperature of $48^{\circ} \mathrm{C}$, followed by thermo-plastic contraction at higher temperature. Creep volume changes, that appeared to be enhanced by temperature, were modelled by using a simple Kelvin-Voigt model, so as to estimate the instantaneous response of the COx claystone and to determine its thermal expansion coefficient. The temperature at which the transition between thermal expansion and contraction appeared is close to the maximum burial temperature of the Callovo-Oxfordian claystone, estimated at $50^{\circ} \mathrm{C}$. This is in agreement with what has been already observed on the Opalinus Clay by Monfared et al. (2013) that was interpreted as a thermal hardening phenomenon, showing that the material kept the memory of the highest temperature supported during its geological history.

Keywords: Thermal volume change, creep, local strains, claystone, Callovo-Oxfordian, saturation.

\section{Introduction}

Many researches have been conducted to better understand the thermal volume changes of clays in link with the disposal at great depth of exothermic high activity radioactive wastes. Besides significant contributions on the thermal volume changes of Boom clay (a possible geological host in Belgium) published by Hueckel and Baldi (1990), Hueckel and Pellegrini (1992), Sultan et al., (2002), recent researches have been carried out on claystones, more particularly on the Callovo-Oxfordian claystone in France and on the Opalinus Clay in Switzerland (including Hohner and Bossart, 1998; Mügler et al., 2006; Muñoz et al., 2009; Monfared et al., 2011b; Mohajerani et al., 2013). Due to the very low permeability of claystones (around $10^{-20} \mathrm{~m}^{2}$ ), tests are difficult and long given that one has to 
ensure good initial saturation and satisfactory drainage of the specimens during testing. In this regard, various systems with reduced drainage length have been proposed, either by adopting specially developed hollow cylinder triaxial apparatus (Monfared et al., 2011a), or by using small sized specimens (Hu et al., 2013), both systems ensuring drainage lengths of $10 \mathrm{~mm}$ allowing satisfactory drainage.

The thermal volume changes of clays submitted to temperature elevation under constant stress depend on their degree of consolidation, with thermoelastic expansion in overconsolidated clays and thermoplastic contraction in normally consolidated clays. In claystones, less data are available. (Monfared et al., 2011b) evidenced a thermal hardening process on the Opalinus Clay, with first a thermoelastic dilation up to the largest temperature experienced during the geological history of the claystone $\left(65^{\circ} \mathrm{C}\right)$ followed by thermoplastic contraction when heating up to $80^{\circ} \mathrm{C}$. Along a subsequent heating/cooling cycle, only thermoelastic dilation occurred with no more contraction at $65^{\circ} \mathrm{C}$, showing that the memory of the historical largest temperature supported has been erased when heating at $80^{\circ} \mathrm{C}$. This feature was however not observed on the Callovo-Oxfordian claystone by Mohajerani et al. (2013) and Menaceur et al. (2015b), who only observed a thermoplastic contraction that could not be suspected from the in-situ thermal experiments in which thermoporoelastic models provided satisfactory responses (Gens et al., 2007).

In this paper, a high precision new thermomechanical isotropic cell allowing a better monitoring of strains along thermomechanical paths is presented. The results of an experimental program aimed at investigating the thermal volume changes of the COx claystone are then presented and analysed.

\section{Material and methods}

\subsection{The Callovo-Oxfordian claystone}

The specimen tested in this study (EST51338) comes from $80 \mathrm{~mm}$ diameter cores extracted at the depth $(490 \mathrm{~m})$ of the Underground Research Laboratory (URL) run by Andra close to the village of Bure (Eastern France). At this level, the COx claystone is composed of a clay matrix (45-50\%) in which some detritic grains of calcite (22-30\%) and quartz (18-32\%) are embedded, together with some other minerals including feldspars (about 5\%), pyrite (less than 2\%). The clay fraction is composed of 10-24\% mixed layer illite/smectite (with 50-70\% smectite), 17-21\% illite, 3-5\% kaolinite, 2-3\% chlorite (Gaucher et al., 2004). The smectite fraction provides to the COx claystone some swelling properties (e.g. Mohajerani et al. (2012) and Delage et al. (2014)) and interesting self-sealing capabilities (Davy et al., 2007; Zhang, 2011; Menaceur et al., 2015b). A detailed investigation of the in-situ state of stress in the Bure URL was conducted by Wileveau et al. (2007), providing the following 
stress values: vertical (lithostatic) total stress $\sigma_{V}$ very close to the minor horizontal stress $\sigma_{h}(\approx 12 \mathrm{MPa})$, a major horizontal stress $\sigma_{H} \approx 1.3 \times \sigma_{V} \approx 16 \mathrm{MPa}$ and (hydrostatic) pore pressure $p_{w}=4.9 \mathrm{MPa}$.

The $80 \mathrm{~mm}$ diameter core of COx was supplied by Andra to the laboratory in a so-called T1 cell, in which the core is wrapped into a neoprene membrane and a cement concrete is cast all around it, inside a PVC cylinder. T1 cells are meant to isolate the core from evaporation and to impose a volume constraint during storage, to minimize damage.

A $38 \mathrm{~mm}$ diameter and $10 \mathrm{~mm}$ height specimen was cored by using a diamond core in the direction perpendicular to the bedding plane and cut at the required length by using a diamond saw. The water content of the core was determined by weighing a sample before and after oven drying at $105^{\circ} \mathrm{C}$ during 48 hours. The sample volume was determined by hydrostatic weighing to calculate the total porosity and the initial degree of saturation. Its initial water content was equal to $6.0 \%$, corresponding to a degree of saturation $S_{r}=87.2 \%$, considering a particle density of $2.70 \mathrm{Mg} / \mathrm{m}^{3}$ (Andra 2005). A suction measurement was carried out on some cuttings of specimen EST51338 by using a chilled mirror tensiometer (WP4, Decagon), providing a value of $36.2 \mathrm{MPa}$. These data are in good compatibility with the water retention curves provided by Pham et al. (2007) and Wan et al. 2013). In the COx claystone, degrees of saturation around $90 \%$ are considered as an indication of good specimen quality. The partial saturation observed is due to the combined effect of stress release, air coring and specimen handling (Monfared et al. 2011, Ewy 2016). The initial characteristics of the tested specimen are presented in Table 1.

\subsection{Experimental device}

The thermal isotropic compression cell used in this work is an extension of a system initially developed by Tang et al. (2008) to investigate the thermal behaviour of compacted bentonites. It was further developed by Mohajerani et al. (2012) to investigate thermal pressurization in the COx claystone. As seen in figure 1a, the cell is surrounded by a heating electric belt allowing temperature control with a precision of $\pm 0.1^{\circ} \mathrm{C}$. It is designed to support pressures up to $60 \mathrm{MPa}$ and temperatures up to $100^{\circ} \mathrm{C}$. The thermal cell is connected to two pressure-volume controllers (PVC, GDS Brand) imposing both the confining and the back pressure up to $60 \mathrm{MPa}$.

In this work, an improvement was carried out by adapting a high precision measurement device for axial and radial strain by using Linear Variable Differential Transformers (LVDTs) on sample with $38 \mathrm{~mm}$ diameter and $10 \mathrm{~mm}$ height, see Belmokhtar et al. (2016). The system of supporting the axial LVDT and the two radial LVDTs is described in the scheme of Figure $1 \mathrm{~b}$ and in the photos of Figure 2. 
The sample was placed on a metal porous disk of $1.2 \mathrm{~mm}$ thickness, resulting in a $10 \mathrm{~mm}$ long drainage length so as to ensure good saturation within a reasonable period of time and good drainage (see Monfared et al. (2011a)). To insulate the sample from the confining fluid (silicone oil), a specially designed cylindrical neoprene membrane able to continuously envelop the top and lateral face of the sample was used, without using any piston or porous disk placed on top of the sample. The membrane was tightly fixed to the bottom base by means of two O-rings.

\subsection{Strain measurement}

Given the stiffness of the COx claystone, with a Young modulus estimated around 4000$5600 \mathrm{MPa}$ (Andra, 2005; Gens et al., 2007; Charlier et al., 2013) and because of the small size of the sample, the displacements during drained compression and heating are expected to be small. Following Sarout et al. (2007), the monitoring of axial and radial displacements was achieved by ensuring direct contact between the LVDT stem and the sample (Figure 2) to avoid any disturbance due to the neoprene membrane. To do so, the membrane was previously pierced with a hole of smaller diameter than that of the stem. Good fluid tightness was ensured by putting a drop of neoprene glue on the membrane around the stem. Using this technique, displacement measurements were improved with a minimum accuracy of $0.1 \mu \mathrm{m}$ corresponding to a strain of $10^{-5}$.

Figure 3 shows a comparison during an undrained compression test between the data of the radial LVDT in direct contact with the specimen through the membrane and that obtained by the axial one in contact with the membrane. Starting from an initial confining stress of $12 \mathrm{MPa}$ with a back-pressure of $4 \mathrm{MPa}$, the confining stress was increased with a loading rate of $20 \mathrm{kPa} / \mathrm{min}$ and maintained at 16.5 MPa during 13 hours. Afterwards, an unloading-reloading path up to a maximum pressure of 18.5 $\mathrm{MPa}$ was followed. Finally, the confining stress was decreased down to $12 \mathrm{MPa}$ with a loading rate of $10 \mathrm{kPa} / \mathrm{min}$. The comparison between the two measurements clearly shows that the LVDT in direct contact with the sample precisely follows all the loading and unloading phases, whereas the measurements made on the membrane do not detect the unloading phases at the 18 and $26^{\text {th }}$ hours. The loading sequence at $20 \mathrm{~h}$ is also poorly monitored. This clearly shows the improvement provided by ensuring a direct contact of the LVDT stem with the specimen through the membrane.

\subsection{Calibration of strains measurements under non-isothermal conditions}

It is necessary to carefully calibrate the strain measurements under elevated temperature, given the parasite thermal strains of the LVDT supporting system that are schematically represented in Figure 4. 
The calibration test was carried out by using a dummy cylindrical steel specimen having the same shape as the COx sample ( $38 \mathrm{~mm}$ diameter and $12 \mathrm{~mm}$ height), under stress conditions close to that prevailing in the field (12 $\mathrm{MPa}$ of confining pressure and $4 \mathrm{MPa}$ of backpressure). Heating was performed with a rate of $1{ }^{\circ} \mathrm{C} / \mathrm{h}$ from $20^{\circ} \mathrm{C}$ to $35^{\circ} \mathrm{C}$. The dilation of steel is known to be isotropic and linear with an expansion coefficient equal to $18 \times 10^{-6}{ }^{\circ} \mathrm{C}^{-1}$.

The measured axial and radial strains are shown in Figure 5 and compared to that provided by calculated the thermal expansion of the dummy specimen. The measured strains are remarkably linear, with an underestimated thermal dilation in the radial direction (radial expansion coefficient $\alpha_{\text {rad }}=4 \times 10^{-}$ $\left.{ }^{6}{ }^{\circ} \mathrm{C}^{-1}\right)$. The axial strains exhibit an unrealistic thermal contraction. These artefacts can easily be interpreted by the thermal dilation of the supporting system as shown in the scheme of Figure 4 that demonstrates that the displacements measured by the LVDTs are under-estimated by the deformation of the supporting system and by the movements of the LVDTs.

The correction method consisted in adopting a linear function to subtract along both the axial and radial directions the parasite displacements due to the thermal dilation of the supporting system. Thereby, the corrected displacement is given by $u_{\text {cor }}=u_{\text {meas }}-C_{i} \times \Delta T$, where $C_{i}$ is the correction coefficient along the direction $i$ given by $C_{\mathrm{rad}}=0.265 \mu \mathrm{m} /{ }^{\circ} \mathrm{C}$ and $C_{\mathrm{ax}}=0.756 \mu \mathrm{m} /{ }^{\circ} \mathrm{C}$.

\section{Experimental results}

\subsection{Saturation phase}

As recommended by Delage et al. (2007) on the Boom clay and by Mohajerani et al. (2012) and Monfared et al. (2012) on claystones, it is important to re-saturate specimens of swelling clays and claystones under stress conditions close to the in-situ ones so as to minimize swelling and damage during hydration. Following these recommendations, the ducts and the porous stone of the cell were kept dry during the sample setup so as to avoid any contact of the sample with water before application of stress. Once the sample placed in the cell, vacuum was applied through the valve located close to the pressure transducer (valve V2 in Figure 1) to evacuate any air trapped between the membrane and the sample. In a first step, the confining pressure was increased to $8 \mathrm{MPa}$, a value close to the mean insitu Terzaghi effective stress. The ducts and porous stone of the drainage system were then carefully saturated by injecting de-aired water in the drainage system through valve V2, while valve V1 was kept closed. Finally, the saturation of the sample was started by simultaneously increasing the confining stress up to $12 \mathrm{MPa}$ and the pore pressure up to $4 \mathrm{MPa}$ at a rate of $100 \mathrm{kPa} / \mathrm{min}$, allowing saturation to be completed under stress conditions close to in-situ. The pore pressure of $4 \mathrm{MPa}$ ensured full dissolution of the micro air bubbles into the pore fluid (Wu et al., 1997). 
Figure 6 shows the change in strain with respect to time measured by the LVDTs during hydration of the specimen with an initial degree of saturation of $87.2 \%$ under constant stress close to in-situ conditions ( $\left.\sigma=12 \mathrm{MPa}, p_{w}=4 \mathrm{MPa}\right)$ during 21 days. One observes that the curve giving the radial strain has a regular shape, whereas that of the axial strain presents some oscillations with an amplitude of $0.001 \%$ corresponding to a displacement of $0.1 \mu \mathrm{m}$ (also indicating the high precision of the displacement measurements). These oscillations are believed to be the consequence of the step regulation of the back pressure (maintained at $4 \mathrm{MPa}$ ) by the $\mathrm{PVC}$, that results in some perturbations at the bottom of the sample and are monitored by the high precision measurement of displacements.

Both the axial and radial LVDTs detect an initial slight swelling phase during the first day, followed by a decrease at longer time until 21 days. They indicate a slight initial volumetric swelling $(0.09 \%)$ with, surprisingly, larger radial strain than axial ones at maximum swelling. The curves afterwards exhibit a decreasing trend, with a clearly anisotropic response and a significantly larger decrease in axial strain compared to radial one. The time dependent strains observed along this 21 days long test correspond to a volumetric creep phenomenon that will be further considered later on. Note that it was unfortunately not possible to monitor the corresponding water exchanges with the sample because of a micro-leak between the back pressure PVC and the cell.

During the saturation phase, previous works carried out on the Callovo-Oxfordian claystone by Mohajerani et al. (2012), Mohajerani et al. (2013), Menaceur et al. (2015a) and Menaceur et al. (2015b) only evidenced a slight swelling with a maximum reached after 2 or 3 days, with no mention of any subsequent creep phase. Most of these tests were however performed during shorter periods (5 days) on the hollow cylinder triaxial apparatus with the LVDT stems not in direct contact with the sample, probably resulting in not being precise enough to detect such tiny contraction strains (around $0.05 \%$ after 5 days).

\subsection{Drained heating under constant in-situ stress}

The thermal volume changes of the Callovo-Oxfordian claystone were investigated by performing a drained heating test from $25^{\circ} \mathrm{C}$ to $80^{\circ} \mathrm{C}$ under close to in-situ stress conditions $\left(\sigma=12 \mathrm{MPa}, p_{w}=4 \mathrm{MPa}\right)$ on sample EST51338. Full drainage condition was ensured thanks to the small drainage length $\left(10 \mathrm{~mm}\right.$, height of the sample) and to the small heating rate applied $\left(0.4^{\circ} \mathrm{C} / \mathrm{h}\right)$, slow enough to avoid any pore pressure excess in sample (Sultan et al. (2002), Monfared et al. (2011), Mohajerani et al. (2013), Menaceur et al. (2015a)). To check the temperature homogeneity in the sample during the experiment, we performed a temperature diffusion analysis in axisymmetric conditions using a finite element simulation. A heating rate of $0.4^{\circ} \mathrm{C} / \mathrm{h}$ was applied to the model 
boundaries between 25 and $80^{\circ} \mathrm{C}$. Considering a value of $1.2 \mathrm{~mm}^{2} / \mathrm{sec}$ for the thermal diffusivity of claystone (calculated from the data given by Gens et al., 2007) the highest temperature difference between the samples boundaries and centre was smaller than $1.2 \times 10^{-3}{ }^{\circ} \mathrm{C}$, showing the homogeneity of the temperature field within the sample.

Valve V1 (Figure 1) was kept open so as to impose a constant pore pressure (4 MPa) by mean of the pressure-volume controller. Heating was made by using the electric belt while the cell was thermally isolated from ambient temperature by means of an isolating cover.

Figure 7 shows a comparison between the measured (Figure 7a) and corrected (Figure 7b) strains. Like for the results presented in Figure 6 and for the same reason, the radial strain response is smooth and regular whereas that of axial strain presents some oscillations. The contraction observed along the heating path with no correction is obviously due to the thermal parasite strains described in Figure 4 that tended to under-estimate the thermal expansion. The corrected strains exhibit a thermal expansion between $25^{\circ} \mathrm{C}$ and $45^{\circ} \mathrm{C}$ followed by a contraction between $45^{\circ} \mathrm{C}$ and $80^{\circ} \mathrm{C}$. Below $45^{\circ} \mathrm{C}$, the curves show that the axial thermal expansion (perpendicular to bedding) is larger than the radial one (parallel to bedding).

\subsection{Volumetric creep under isotropic stress}

Before and after running the drained heating test of Figure 7, the sample was kept under constant isotropic confining pressure $\left(\sigma_{d}=8 \mathrm{MPa}\right)$ at temperatures of $25^{\circ} \mathrm{C}$ and $80^{\circ} \mathrm{C}$ for periods of time of 19 and 16 days, respectively. The measured axial and radial strains are plotted in Figure $8 \mathrm{a}$ and $\mathrm{b}$ at both temperatures. A time dependent anisotropic compaction is observed under both temperatures, evidencing a volumetric creep response under constant isotropic stress, with axial creep strain larger than radial one. One also observes that creep strains are larger at elevated temperature. Actually, the creep rates calculated at both temperatures at times larger than 10 days do not differ too much, with an axial strain rate (perpendicular to bedding) of $4.8 \times 10^{-10} \mathrm{~s}^{-1}$ at $25^{\circ} \mathrm{C}$ compared to $3.5 \times 10^{-10} \mathrm{~s}^{-1}$ at $80^{\circ} \mathrm{C}$ and a radial one of $1.5 \times 10^{-10} \mathrm{~s}^{-1}$ at $25^{\circ} \mathrm{C}$ compared to $0.9 \times 10^{-10} \mathrm{~s}^{-1}$ at $80^{\circ} \mathrm{C}$. The larger creep strain observed at $80^{\circ} \mathrm{C}$ mainly appears during the first 8 days and the creep rates along both axial and radial directions after 10 days are actually smaller at $80^{\circ} \mathrm{C}$.

The volume changes observed all along the test are represented in Figure 9, showing successively the volumetric creep at $25^{\circ} \mathrm{C}$ followed by the thermal contraction/expansion phase observed under drained heating from $25^{\circ} \mathrm{C}$ to $80^{\circ} \mathrm{C}$ with finally the volumetric creep at $80^{\circ} \mathrm{C}$. This curve suggests that some creep should occur also during the heating phase, and that the thermal dilation coefficients cannot be directly extracted from the curves of Figure $8 b$. 


\section{Discussion and interpretation}

\subsection{Creep}

Except for the work of Gasc-Barbier et al. (2004), most published creep investigations on the COx claystone have been carried out in partially saturated states. No data are available on creep under constant isotropic stress. The samples tested in Gasc-Barbier et al. (2004) were saturated under an isotropic stress of $12 \mathrm{MPa}$ and a pore pressure of $5 \mathrm{MPa}$, close to the in-situ stress state at $492 \mathrm{~m}$ depth where their specimens have been extracted, and to that applied in this work $\left(\sigma=12 \mathrm{MPa}\right.$ and $p_{w}=4$ $\mathrm{MPa})$. They applied constant axial stresses of 10, 25, 50 and $75 \%$ of the failure shear stress (20 MPa) at both $20^{\circ} \mathrm{C}$ and $80^{\circ} \mathrm{C}$, with test durations of 1 or 2 months.

Other investigations include the uniaxial creep tests of Fabre and Pellet (2006), with a degree of saturation $S_{r}=87 \%$ under an axial stress of $26 \mathrm{MPa}\left(90 \% q_{\text {peak }}\right)$ and the creep tests on specimens equilibrated under $90 \%$ relative humidity $\left(S_{r}\right.$ around 90\%) under confining stresses of $2 \mathrm{MPa}$ and $12 \mathrm{MPa}$ and axial stresses of 50, 75 and 90\% peak stress of Armand et al. (2016). Zhang et al. (2010) observed from uniaxial creep tests a significant decrease in creep with decrease in degree of saturation.

At comparable time scales, the axial creep rates obtained in these unsaturated tests $\left(2.9 \times 10^{-10} \mathrm{~s}^{-1}\right.$ for Armand et al. (2016) at 50\% $q_{\text {peak }}$ under $12 \mathrm{MPa}$ or $3.7 \times 10^{-10} \mathrm{~s}^{-1}$ for Fabre and Pellet (2006) at $90 \%$ $\left.q_{\text {peak }}\right)$ are in the same order of magnitude than what has been obtained in this work at $25^{\circ} \mathrm{C}\left(4.8 \times 10^{-10} \mathrm{~s}^{-}\right.$ ${ }^{1}$ ). The comparison is however not so relevant, given the significantly different conditions: partial saturation reduces the creep rate whereas the application of a differential stress increases it.

For some reasons, the axial creep rate of Gasc-Barbier et al. (2004) on saturated samples under in-situ stress conditions and $10 \% q_{\text {peak }}$ are significantly smaller $\left(0.8 \times 10^{-10} \mathrm{~s}^{-1}\right)$ than ours. Their axial creep rate at $80^{\circ} \mathrm{C}\left(0.6 \times 10^{-10} \mathrm{~s}^{-1}\right)$ is comparable to that at $25^{\circ} \mathrm{C}$, like in our case, with also large creep strain obtained during the first days, like in Figure $8 \mathrm{~b}$. This difference is difficult to explain, and the differences in specimen composition and experimental procedures might be involved. In our case, high precision local strain measurements with direct contact with the sample were carried out, whereas axial strain measurements in triaxial cells may be affected by friction effects between piston and cell.

Of course, some precautions should be taken when extrapolating the experimental creep data obtained here in laboratory tests to the in-situ intact rock mass, due to possible damage caused to the sample after the successive stages of air coring, core handling after extraction, core storage in the T1 cell and specimen handling and trimming prior to laboratory testing. We have no information about the quality of the specimens tested in the other creep investigations mentioned above but, as commented 
earlier, the $87.2 \% S_{r}$ value of our specimen is considered as that of a good quality specimen, and the swelling observed during saturation under in-situ stress is quite small $(0.09 \%)$.

Definitely, extrapolation to in-situ conditions should be made in close relation with in-situ data on the time dependent response of the rock mass, given that damage tends to over-estimate creep. This is however not straightforward, given that the convergence measurements made around the drift in the Bure URL involves the mobilisation of discontinuities in the Excavation damaged zone (EDZ), as commented in Armand et al. (2013) (see also Guayacán-Carrillo et al. 2016). Armand et al. (2013) mention orders of magnitude between 5 and $1 \times 10^{-5} \mathrm{~s}^{-1}$ after between 100 and 1000 days, depending on the location of the measurement point on the gallery wall (roof, edge) and of the orientation of the gallery with respect to the horizontal major and minor stresses.

\subsection{Effects of volumetric creep on thermal strains}

The drained heating test presented in Figure 7 was aimed at characterising the thermal volume changes of the COx claystone submitted to temperature elevation under stress conditions close to insitu. The data obtained clearly evidenced some creep strains at both temperatures, with larger creep strains at $80^{\circ} \mathrm{C}$ compared to $25^{\circ} \mathrm{C}$. Experimental data indicated that axial creep strains (perpendicular to bedding) were significantly larger than radial creep strain (parallel to bedding). This is a general feature of the deformability of claystones. It is probably related to the effect of the water molecules adsorbed along the clay minerals within platelets (see Menaceur et al. 2016) that have a preferential horizontal orientation. It seems that this feature has seldom been observed in terms of creep strains.

Creep deformations hence have to be considered in more detail to separate time dependent strains from the instantaneous thermal response of the claystone, so as to determine the thermo-elastic expansion coefficient. The time-dependent behaviour of COx claystone has been modelled by several authors using viscoplastic constitutive models (e.g. Shao et al. 2003, 2006, Liu et al. 2015, Pardoen and Collin 2016). For sake of simplicity, it was however preferred in a first attempt to adopt a basic viscoelastic Kelvin-Voigt rheological model made up of an elastic spring with bulk modulus $K$ connected in parallel with a viscous damper of viscosity $\eta$, following the approaches adopted by Ghabezloo et al. (2008), Ghabezloo et al. (2009) and Vu et al. (2012) on hardened cement pastes.

Assuming that creep strains are governed by the Terzaghi effective stress $\sigma$, the effective stress $\sigma^{\prime}$ is given as a function of the viscoelastic volumetric strain $\varepsilon^{v e}$ by the following expression:

$$
\sigma^{\prime}=K_{k v} \varepsilon^{v e}+\eta \frac{d \varepsilon^{v e}}{d t}
$$


In the case of a creep experiment under constant stress and temperature with constant material parameters $K_{k v}$ and $\eta$, a closed-form solution of equation (1) can easily be found to determine the timedependent viscoelastic volumetric strains. However, the increase in creep strain rate with temperature under constant stress state observed here evidences a significant temperature dependency of the model parameters. As a consequence, equation (1) cannot be solved analytically any longer. A finite difference solution using the Crank-Nicolson scheme given in equation (2) was therefore used.

$$
\varepsilon^{v e}=\frac{\varepsilon_{0}^{v e}+\frac{1}{\eta}\left(\sigma^{\prime}-K_{k v} \theta \varepsilon_{0}^{v e}\right) \Delta t}{1+\frac{K_{k v}}{\eta}(1-\theta) \Delta t}
$$

in which $\varepsilon_{\varepsilon}$ and $\varepsilon_{0}$ are the volumetric strains at current and previous time step, respectively, $\Delta t$ is the time step and $\theta=1 / 2$ following the Crank-Nicolson scheme.

The values of parameters $K_{k v}$ and $\eta$ were fitted separately at $25^{\circ} \mathrm{C}$ and $80^{\circ} \mathrm{C}$ by simulating the creep strains using the finite difference method. A least square error minimization was used to fit the best values of the parameters presented in Table 2. The comparison of the simulated and experimental creep strains presented in Figure 11 shows good compatibility.

It is interesting to note the significant effect of temperature on the time-dependent behaviour, as reflected by the decrease in both the modulus $K_{k v}$ (from $3500 \mathrm{MPa}$ at $25^{\circ} \mathrm{C}$ to $1000 \mathrm{MPa}$ at $80^{\circ} \mathrm{C}$ ) and the viscosity $\eta$ (from $5.0 \times 10^{7} \mathrm{MPa}$.min at $25^{\circ} \mathrm{C}$ to $0.4 \times 10^{7} \mathrm{MPa}$.min at $80^{\circ} \mathrm{C}$ ). The simulation of the creep strains under increased temperature, necessary to correct the experimental thermal strains, requires continuous functions for the temperature dependency of viscoelastic parameters. As seen in Equations 3 and 4, an exponential temperature dependency was assumed for model parameters $K_{k v}$ and $\eta$, that were evaluated by fitting the parameters at temperatures $T_{0}$ and $T_{1}$.

$$
\begin{gathered}
K_{k v}(T)=K_{k v}\left(T_{0}\right) e^{a\left(T-T_{0}\right)} ; a=\frac{\ln \left(K_{k v}\left(T_{1}\right)\right)-\ln \left(K_{k v}\left(T_{0}\right)\right)}{T_{1}-T_{0}} \\
\eta(T)=\eta\left(T_{0}\right) e^{b\left(T-T_{0}\right)} ; b=\frac{\ln \left(\eta\left(T_{1}\right)\right)-\ln \left(\eta\left(T_{0}\right)\right)}{T_{1}-T_{0}}
\end{gathered}
$$

The measured volumetric strains during the overall test including creep phases and the drained heating phase are now compared with the simulation results in Figure 12, confirming again the excellent estimation of the creep strains using the fitted viscoelastic model.

Note however that this simple approach was fitted on the creep phases of the test at 25 and $80^{\circ} \mathrm{C}$ and doesn't account for possible effects of the contraction/expansion response observed during the 
drained heating test, before the creep phase at $80^{\circ} \mathrm{C}$. The main aim of this simple model is to provide a reasonable estimation of the creep strain at 25 and $80^{\circ} \mathrm{C}$, so as to provide a more precise determination of the instantaneous thermal response of the claystone.

This is done in Figure 13 in which the simulated creep volumetric strain was subtracted from the measured total strain volumetric strain. Comparing the volumetric strains with and without creep in Figure 13 shows the significant effect of creep on the volumetric response under heating, particularly for the thermal contraction phase. The corrected curve now permits the determination of the drained thermal expansion coefficient $\alpha_{d}$ of the COx claystone, equal to $4.82 \times 10^{-5}\left({ }^{\circ} \mathrm{C}\right)^{-1}$. The volumetric thermal contraction coefficient $C_{T}$ is equal to $1.82 \times 10^{-5}\left({ }^{\circ} \mathrm{C}\right)^{-1}$.

\section{Verification of the drainage conditions}

It is important to check whether the slow heating rate adopted $\left(0.4^{\circ} \mathrm{C} / \mathrm{h}\right)$ ensured fully drained conditions during the heating test, so as to make sure that the volume changes measured were really representative of thermal and creep strain, with no artefact due to the generation of thermal excess pore pressures. To do so, one considered the general differential equation governing the thermal consolidation of a visco-elastic porous medium, as follows:

$$
\frac{\mathrm{d} p_{f}}{\mathrm{~d} t}=B \frac{\mathrm{d} \sigma}{\mathrm{d} t}+\Lambda \frac{\mathrm{d} T}{\mathrm{~d} t}+\beta_{u} \frac{\mathrm{d} \varepsilon^{v e}}{\mathrm{~d} t}+\frac{\beta_{u}}{\rho_{f}} \frac{\partial}{\partial z}\left(k \frac{\rho_{f}}{\mu_{f}} \frac{\partial p_{f}}{\partial z}\right)
$$

This equation is written for a 1D problem of a porous medium under isotropic stress. A detailed derivation is presented in Ghabezloo et al. (2009). In this equation, $B$ is the Skempton coefficient, $\Lambda$ is the thermal pressurization coefficient, $k$ is the intrinsic permeability, $\rho_{f}$ and $\mu_{f}$ are the water density and viscosity, respectively. $\beta_{u}$ is the storage coefficient given by:

$$
\beta_{u}=\left[\frac{1}{K_{d}}-\frac{1}{K_{s}}+\phi_{0}\left(\frac{1}{K_{f}}-\frac{1}{K_{\phi}}\right)\right]^{-1}
$$

where $K_{d}$ is the drained bulk modulus, $K_{s}$ is the unjacketed modulus, $K_{f}$ is the fluid compression modulus and $K_{\phi}$ is the unjacketed pore volume modulus which is assumed to be equal to $K_{s}$. Equation (5) shows that the compressive volumetric visco-elastic strains $\varepsilon^{v e}$, given by equation (1), generate some excess pore pressure in the medium. The volumetric strain is given by:

$$
\mathrm{d} \varepsilon=\frac{1}{K_{d}}\left(\mathrm{~d} \sigma-b \mathrm{~d} p_{f}\right)-\alpha_{d} \mathrm{~d} T+\mathrm{d} \varepsilon^{v e}
$$

where $b$ is Biot's effective stress coefficient $\left(b=1-K_{d} / K_{s}\right)$ and $\alpha_{d}$ is the volumetric drained thermal expansion coefficient. 
In our test, the constant stress condition results in having the term $\mathrm{d} \sigma / \mathrm{d} t$ equal to zero. Excess pore pressure hence results from i) the differential thermal expansion between water and the solid phase, governed by parameter $\Lambda$ and by the heating rate $\mathrm{d} T / \mathrm{d} t\left(0.4^{\circ} \mathrm{C} / \mathrm{h}\right)$, ii) the pore pressure dissipation, governed by the material permeability and iii) the visco-elastic strains, given here by the Kelvin-Voigt model. The pressure and temperature dependencies of the water viscosity, density and compression modulus are taken into account in the simulation.

A finite difference solution was used to solve equation (5). The same loading path as that presented in Figure 9 was applied to the sample, with a first 18.5 days long stage during which the confining pressure and temperature were kept constant. The creep strains generate some excess pore pressure that results in a pore pressure gradient and a flow of the fluid out of the sample. During the second stage, temperature was increased at a constant rate of $0.4 \%$ from 25 to $80^{\circ} \mathrm{C}$, resulting in a thermo-elastic expansion of the sample coupled with an excess pore pressure generation governed by the thermal pressurization coefficient $\Lambda$. As can be seen in equations (3) and (4), the parameters of the viscoelastic model change with temperature, resulting in more significant creep strains at higher temperature, which in turn result in higher excess pore pressure. Temperature increase also results in a decrease of the water dynamic viscosity and an acceleration of the pore pressure dissipation through the diffusion term in equation (5). The results of the simulation are presented in Figures 13 and 14, that give the change in volumetric strains and pore pressure at the top of the sample ( $x$ axis) with respect to temperature ( $y$ axis), respectively. Pore pressure values are provided at $10 \mathrm{~mm}$ from the bottom porous disk, where the highest values are obtained. Three different cases are compared: 1) a thermo-poroelastic medium without any creep strains, 2) a thermo-visco-poro-elastic medium with constant viscoelastic parameters equal to that at $25^{\circ} \mathrm{C}$ and 3) the main case, a thermo-visco-poro-elastic medium with temperature-dependent viscoelastic parameters following Equations 3 and 4. The material parameters used are summarized in the Table 3 below, where the thermal pressurization coefficient is taken from Mohajerani et al. (2012) and the poroelastic parameters from Belmokhtar et al. (2017).

The changes in volumetric strain in Figure 13 show a linear thermal expansion of the sample during the heating phase for case 1), with no creep strains in phases under constant temperature. The pore pressure response in Figure 14 shows an initial increase of about $34 \mathrm{kPa}$ at the beginning of the heating phase. Then, diffusion results in a progressive decrease of the pore pressure which continues at the last stage under constant temperature. The results of case 2) with constant creep parameters show similar tendency, but with some contracting creep strains and larger excess pore pressures. Note that in both cases, the competition between the pore pressure generation (due to thermal pressurization in both cases and also to creep strains in case 2)) and the pore pressure dissipation (enhanced by 
temperature increase due to the reduction in water viscosity) results in a progressive decrease of the pore pressure during the heating phase. In case 3) where the temperature dependency of the creep parameters is taken into account, the creep strains are significantly enhanced at higher temperature, resulting in a contraction of the medium, even during the heating phase. This results in larger excess pore pressures compared to cases 1) and 2). In all cases, the maximum simulated excess pore pressure at the sample top is quite low, smaller than $37 \mathrm{kPa}$. The volumetric strain resulting from this excess pore pressure are in the order of $1 \times 10^{-5}$, a negligible value compared to the volumetric strains measured in the test. As a conclusion, it can be stated that the heating rate adopted is satisfactory to ensure good drainage conditions, hence providing the intrinsic response of the material with no artefacts due to excess pore pressures.

\subsection{Discussion on the thermal volume changes}

Whereas the thermal volume changes of clays are more documented, following the pioneering contribution of Hueckel and Baldi (1990), rather few data are available on claystones and shales. The drained heating test carried out in this work was aimed at investigating the thermal response of the COx claystone under stress conditions close to in-situ ones. The results showed a volumetric creep during the saturation phase at $25^{\circ} \mathrm{C}$ and at $80^{\circ} \mathrm{C}$, after a drained heating test. A simple viscoelastic approach was used to subtract the creep volumetric strains from the total volumetric strains measured, so as to investigate the instantaneous thermomechanical response of the COx claystone.

At the beginning of heating (between 25 and $45^{\circ} \mathrm{C}$ ), this response is thermoelastic, as already observed in other clays and claystones. Some degree of anisotropy was also observed, and a thermal volumetric expansion coefficient $\alpha_{d}$ of $4.82 \times 10^{-5}\left({ }^{\circ} \mathrm{C}\right)^{-1}$ was obtained. This response, similar to that traditionally observed in natural overconsolidated soils (e.g. Hueckel and Baldi 1990 and Sultan et al., 2002 on Boom clay, Abuel-Naga et al. 2007 on Bangkok clay), is comparable to that of another claystone, the Opalinus Clay, for which Monfared et al. (2011) determined a comparable thermo-elastic volumetric expansion coefficient $\alpha_{d}=5.9 \times 10^{-5}\left({ }^{\circ} \mathrm{C}\right)^{-1}$. Other published values of thermo-elastic volumetric expansion coefficients include that provided by Auvray (2004) in Gens et al. (2007) $\left(\alpha_{d}=4.5 \times 10^{-5}\left({ }^{\circ} \mathrm{C}\right)^{-1}\right)$ and that used in Muñoz et al. $\left(2009, \alpha_{d}=4.05 \times 10^{-5}\left({ }^{\circ} \mathrm{C}\right)^{-1}\right)$, from data from Hohner and Bossart (1998).

The value obtained here is in the range of other values provided on claystones, with actually rather small variability observed in data from various labs. They are also in the same order of magnitude, although a little bit larger, than the thermal expansion coefficients of various minerals given in the literature presented in Table 4 (see also Ghabezloo and Sulem (2009) and Delage (2013)). The 
thermal expansion coefficient of the clay matrix (that constitutes around 50\% of the COx claystone) is $3.4 \times 10^{-5}\left({ }^{\circ} \mathrm{C}\right)^{-1}$, close to that of quartz minerals $(22 \%$ of the COx claystone) whereas the thermal expansion coefficients of calcite $(28 \%)$ and feldspars are smaller.

Observation of the thermal strains of Figure 7 shows that axial thermal strains are larger than the radial ones. These strains are due to the combined effect of temperature elevation (thermo-elastic strains) and creep strains, with also some increase in creep rate with increased temperature. It is hence somewhat difficult to draw any conclusion about the anisotropy that would affect instantaneous thermo-elastic strains. At a first glance, one could suspect from Figure 7 that axial thermo-elastic strains could be larger than radial ones, but this conclusion needs to be further confirmed. It is not in agreement with data from Auvray (2004), who obtained a smaller thermo-elastic linear expansion coefficient perpendicular to the bedding plane $\left(\alpha_{\perp}=1.1 \times 10^{-5}\left({ }^{\circ} \mathrm{C}\right)^{-1}\right)$ than parallel to bedding $\left(\alpha_{/ /}=1.7 \times 10^{-5}\left({ }^{\circ} \mathrm{C}\right)^{-}\right.$ $\left.{ }^{1}\right)$. The combination of both values led to the value of volumetric thermal expansion coefficient $\alpha_{d}=4.5 \times 10^{-5}\left({ }^{\circ} \mathrm{C}\right)^{-1}$ mentioned above. Further investigation is needed in this respect.

The thermo-elastic phase observed in Figure 7 is followed, above $48^{\circ} \mathrm{C}$, by a plastic contraction also characterised by radial strain larger than axial ones, providing a volumetric thermal contraction coefficient $C_{T}=1.8 \times 10^{-5}\left({ }^{\circ} \mathrm{C}\right)^{-1}$. The transition between thermoelastic expansion and thermoplastic contraction observed in Figure 13 is typical of overconsolidated clays (e.g. Baldi et al. (1988) and Sultan et al. (2002) on the Boom clay, Abuel-Naga et al. 2007 on Bangkok clay). Mohajerani et al., (2013) also observed this trend under in-situ stress conditions on a COx specimen previously submitted to stress larger than in-situ. It has also been observed on the Opalinus Clay by Monfared et al. (2011b), at a temperature equal to the highest one experienced by the clay during its geological history. Interestingly, this is also true here, since Blaise et al., (2014) determined for the COx claystone a maximum burial temperature of $50 \pm 5^{\circ} \mathrm{C}$, to compare with the temperature of $48^{\circ} \mathrm{C}$ at which the transition between thermoelastic compression and plastic contraction is observed on the COx claystone (Figure 13). This means that the claystone kept the memory of the highest experienced temperature, below which it exhibits a thermoelastic expansion. In other words, temperature has an effect comparable to that of stress, with an elastic response in a range of temperature already supported, followed by yielding and plastic contraction when this limit is passed, exhibiting a thermal hardening behaviour. This is compatible with existing thermo-plastic models that provide a definition of an elastic zone and of a yield curve in the $p, T$ plane (e.g. Hueckel and Borsetto 1990, Sultan et al. 2002). 


\section{Conclusion}

The development of a high precision local strain monitoring system with two radial and an axial LVDT with stems directly put in contact with the specimen through the membrane allowed to precisely follow the mechanical and thermal volume strains induced by a drained temperature elevation under stress conditions close to in-situ ones. A first consequence of this enhanced precision was the observation of anisotropic creep strains under constant isotropic stress at ambient temperature and at $80^{\circ} \mathrm{C}$.

Careful calibration of the thermal deformations of the system were carried out to get the exact strains during the drained heating test. Comparison with other published data on the COx claystone are not straightforward due to different testing conditions, in terms of partial saturation of the specimens, of application of confining or axial stress during the creep test.

A satisfactory fit of the creep volumetric strain at 25 and $80^{\circ} \mathrm{C}$ was obtained by adopting a simple viscoelastic Kelvin-Voigt model. This model, that accounted for the increase in creep strain with temperature, allowed to subtract the creep strain to the total strain so as to determine the instantaneous thermal response of the COx claystone. The creep enhancement with temperature resulted in the decrease in both the modulus $K_{k v}$ (from 3500 to $1000 \mathrm{MPa}$ ) and the viscosity $\eta$ (from $5.0 \times 10^{7}$ to 0.4 $\times 10^{7} \mathrm{MPa}$.min) when passing from 25 to $80^{\circ} \mathrm{C}$.

Observation of the instantaneous strains showed that heating under constant in-situ stress led first to thermo-elastic expansion up to a temperature of $48^{\circ} \mathrm{C}$, close to the maximum burial temperature experienced by the claystone $\left(50^{\circ} \mathrm{C}\right)$. This dilation was followed by yielding and thermo-plastic contraction, as observed in the Opalinus Clay (Monfared et al., 2011b). The thermal hardening phenomenon evidenced in the Opalinus Clay is then also observed on the Callovo-Oxfordian claystone.

These results are thought to be of some interest when calculating the volume changes generated by temperature elevation around the waste disposal cells at great depth, showing that the thermoporoelastic assumption is valid up to a certain temperature. Above $48^{\circ} \mathrm{C}$, thermoplastic contraction will probably result in some stress redistribution that should be accounted for.

\section{References}

Abuel-Naga H.M., Bergado D.T., Bouazza A. 2007. Thermally induced volume change and excess pore water pressure of soft Bangkok clay. Eng Geol 89: 144-154

Andra (2005) Synthesis argile: evaluation of the feasibility of a geological repository in argillaceous formation. < http://www.andra.fr/download/site-principal/document/editions/266.pdf >. 
Armand G, Noiret A, Zghondi J, Seyedi DM (2013) Short- and long-term behaviors of drifts in the Callovo-Oxfordian claystone at the Meuse/Haute-Marne Underground Research Laboratory. J Rock Mech Geotech Eng 5:221-230.

Armand G, Conil N, Talandier J, Seyedi D M (2016) Fundamental aspects of the hydromechanical behaviour of Callovo-Oxfordian claystone: From experimental studies to model calibration and validation. Comp Geotech, http://dx.doi.org/10.1016/j.compgeo.2016.06.003.

Auvray C (2004) Thermomechanical tests on Opalinus Clays of the Mont Terri, ANDRA Report C.RP.OENG.04-0239.

Baldi G, Hueckel T, Pellegrini R (1988) Thermal volume changes of the mineral-water system in low-porosity clay soils. Can Geotech J 25:807-825.

Belmokhtar M, Delage P, Ghabezloo S, et al (2017) Poroelasticity of the Callovo-Oxfordian Claystone. Rock Mech Rock Eng 50:871-889. doi: 10.1007/s00603-016-1137-3

Blaise T, Barbarand J, Kars M, Ploquin F, Aubourg C, Brigaud B, Cathelineau M, El Albani A, Gautheron C, Izart A, Janots D, Michels R, Pagel M, Pozzi J-P, Boiro M C, Landrein P (2014) Reconstruction of low temperature $\left(<100^{\circ} \mathrm{C}\right)$ burial in sedimentary basins: A comparison of geothermometer in the intracontinental Paris Basin. Mar Pet Geol 53:71-87.

Charlier R, Collin F, Pardoen B, Talandier J, Radu J-P, Gerard P (2013) An unsaturated hydromechanical modelling of two in-situ experiments in Callovo-Oxfordian argillite. Eng Geol 165:46-63.

Davy C A, Skoczylas F, Barnichon J-D, Lebon P (2007) Permeability of macro-cracked argillite under confinement: Gas and water testing. Phys Chem Earth, Parts A/B/C 32:667-680.

Delage $\mathrm{P}$ (2013) On the thermal impact on the excavation damaged zone around deep radioactive waste disposal. J Rock Mech Geotech Eng 5:179-190.

Delage P, Le T-T, Tang A-M, Li X-L (2007) Suction effects in deep Boom clay block samples. Géotechnique 57:239-44.

Delage P, Menaceur H, Tang A-M, Talandier J (2014) Suction effects in deep Callovo-Oxfordian claystone. Geot Lett 3:84-88.

Fabre G, Pellet F (2006) Creep and time-dependent damage in argillaceous rocks. Int J Rock Mech Min Sci 43:950-960. doi: 10.1016/j.ijrmms.2006.02.004

Fei Y (1995) Thermal expansion. In: Thomas JA, editor. Mineral Physics and Crystallography: A Handbook of Physical Constants. Miner Phys Crystallogr A Handb Phys Constants Washington, DC Amer Geophys Union 29-44.

Gasc-Barbier M, Chanchole S, Bérest P (2004) Creep behavior of Bure clayey rock. Appl Clay Sci 26:449-458. doi: 10.1016/j.clay.2003.12.030

Gaucher E, Robelin C, Matray J-M, Négrel G, Gros Y, Heitz J-F, Vinsot A, Rebours H, Cassagnabère A, Bouchet A (2004) ANDRA underground research laboratory: Interpretation of the mineralogical and geochemical data acquired in the Callovian-Oxfordian formation by investigative drilling. Phys Chem Earth 29:55-77.

Gens A, Vaunat J, Garitte B, Wileveau Y (2007) In situ behaviour of a stiff layered clay subject to thermal loading: observations and interpretation. Géotechnique 207-228.

Ghabezloo S, Sulem J (2009) Stress dependent thermal pressurization of a fluid-saturated rock. Rock Mech Rock Eng 42:1-24.

Ghabezloo S, Sulem J, Guédon S, Martineau F, Saint-Marc J (2008) Poromechanical behaviour of hardened cement paste under isotropic loading. Cem Concr Res 38:1424-1437. 
Ghabezloo S, Sulem J, Saint-Marc J (2009) Evaluation of a permeability-porosity relationship in a low-permeability creeping material using a single transient test. Int J Rock Mech Min Sci 46:761768.

Guayacán-Carrillo LM, Sulem J, Seyedi DM, Ghabezloo S, Noiret A, Armand G (2016) Analysis of long-term anisotropic convergence in drifts excavated in Callovo-Oxfordian claystone. Rock Mech Rock Eng, 49(1): 97-114.

Hohner M, Bossart P (1998) Geological, mineralogical, geochemical, geomechanical and hydraulic parameters of Opalinus Clay derived by in-situ and laboratory experiments, Mont Terri Technical Note 98-49.

Hu DW, Zhang F, Shao JF (2013) Experimental study of poromechanical behavior of saturated claystone under triaxial compression. Acta Geotech 31-36.

Hueckel T, Baldi G (1990) Thermoplasticity of saturaed clays: experimental constitutive study. J Geotech Eng ASCE, 116:1778-1796.

Hueckel T, Borsetto M (1990) Thermoplasticity of saturated soils and shales: Constitutive equations. J Geotech Eng, ASCE, 116 (12), 1765-1777.

Hueckel T, Pellegrini R (1992) Effective stress and water pressure in saturated clays during heating-cooling cycles. Can Geotech J 29:1095-1102.

Liu ZB, Xie SY, Shao JF, Conil N (2015) Effects of deviatoric stress and structural anisotropy on compressive creep behavior of a clayey rock. Appl Clay Sci 114:491-496. doi: 10.1016/j.clay.2015.06.039

McTigue DF (1986) Thermoelastic Response of Fluid-Saturated Porous Rock. J Geophys Res 91:9533-9542.

Menaceur H, Delage P, Tang A-M, Conil N (2015a) On the Thermo-Hydro-Mechanical Behaviour of a Sheared Callovo-Oxfordian Claystone Sample with Respect to the EDZ Behaviour. Rock Mech Rock Eng 6-8.

Menaceur H, Delage P, Tang A-M, Conil N (2015b) The thermo-mechanical behaviour of the Callovo-Oxfordian claystone. Int J Rock Mech Min Sci 78:290-303.

Menaceur H., Delage P., Tang A.M. and Talandier J. 2016. The status of water in swelling shales: an insight from the water retention properties of the Callovo-Oxfordian claystone. Rock Mechanics and Rock Engineering 49 (12).

Mohajerani M, Delage P, Sulem J, Monfared M, Tang A-M, Gatmiri B (2013) The Thermal Volume Changes of the Callovo-Oxfordian Claystone. Rock Mech Rock Eng 47:131-142.

Mohajerani M, Delage P, Sulem J, Monfared M, Tang A-M, Gatmiri B (2012) A laboratory investigation of thermally induced pore pressures in the Callovo-Oxfordian claystone. Int J Rock Mech Min Sci 52:112-121.

Monfared M, Delage P, Sulem J, Mohajerani M, Tang A-M, De Laure E (2011a) A new hollow cylinder triaxial cell to study the behaviour of geo-materials with low permeability. Int J Rock Mech Min Sci 48:637-649.

Monfared M, Sulem J, Delage P, Mohajerani M (2011b) A Laboratory Investigation on Thermal Properties of the Opalinus Claystone. Rock Mech Rock Eng 44:735-747.

Monfared M, Sulem J, Delage P, Mohajerani M (2012) On the THM behaviour of a sheared Boom clay sample: Application to the behaviour and sealing properties of the EDZ. Eng Geol 124:4758. 
Mügler C, Filippi M, Montarnal P, Montarnal Ph, Martinez J-M, Wileveau Y (2006) Determination of the thermal conductivity of Opalinus Clay via simulations of experiments performed at the Mont Terri underground laboratory. J Appl Geophys 58:112-129. doi: 10.1016/j.jappgeo.2005.05.002

Muñoz J, Alonso EE, Lloret A (2009) Thermo-hydraulic characterisation of soft rock by means of heating pulse tests. Géotechnique 59:293-306.

Palciauskas V, Domenico PA (1982) Characterization of drained and undrained response of thermally loaded repository rocks. Water Resour Res 18:281-290.

Pardoen B, Collin F. (2016) Modelling the influence of strain localisation and viscosity on the behaviour of underground drifts drilled in claystone. Comput Geotech, http://dx.doi.org/10.1016/j.compgeo.2016.05.017

Pham QT, Vales F, Malinsky L, Nguyen M-D, Gharbi H (2007) Effects of desaturationresaturation on mudstone. Phys Chem Earth, Parts A/B/C 32:646-655.

Sarout J, Molez L, Guéguen Y, Hoteit N (2007) Shale dynamic properties and anisotropy under triaxial loading: Experimental and theoretical investigations. Phys Chem Earth, Parts A/B/C 32:896906.

Shao JF, Zhu QZ, Su K. (2003) Modeling of creep in rock materials in terms of material degradation. Comput Geotech 30(7):549-55.

Shao JF, Chau KT, Feng XT. (2006) Modeling of anisotropic damage and creep deformation in brittle rocks. Int J Rock Mech Min Sci 43(4):582-92.

Spang B (2002) Excel add-in for properties of water and steam in SIunits. http://www.cheresources.com/iapwsif97.shtml.

Sultan N, Delage P, Cui Y (2002) Temperature effects on the volume change behaviour of Boom clay. Eng Geol 64:135-145.

Tang A-M, Cui Y-J, Barnel N (2008) Thermo-mechanical behaviour of a compacted swelling clay. Géotechnique 58:45-54.

Vu M-H, Sulem J, Ghabezloo S, Laudet J-B, Garnier A, Guédon S (2012) Time-dependent behaviour of hardened cement paste under isotropic loading. Cem Concr Res 42:789-797. doi: 10.1016/j.cemconres.2012.03.002

Wan M, Delage P, Tang A-M, Talandier J (2013) Water retention properties of the CallovoOxfordian claystone. Int J Rock Mech Min Sci 64:96-104.

Wu B, Tan CP, Aoki T (1997) Specially designed techniques for conducting consolidated undrained triaxial tests on low permeability shales. Int J Rock Mech Min Sci 34:336.e1-336.e14. doi: 10.1016/S1365-1609(97)00168-8

Zhang CL (2011) Experimental evidence for self-sealing of fractures in claystone. Phys Chem Earth 36:1972-1980.

Zhang CL, Czaikowski O, Rothfuchs T (2010) Thermo-Hydro- Mechanical Behaviour of the Callovo- Oxfordian Clay Rock. Rep GRS-266 264. 


\section{Figures}

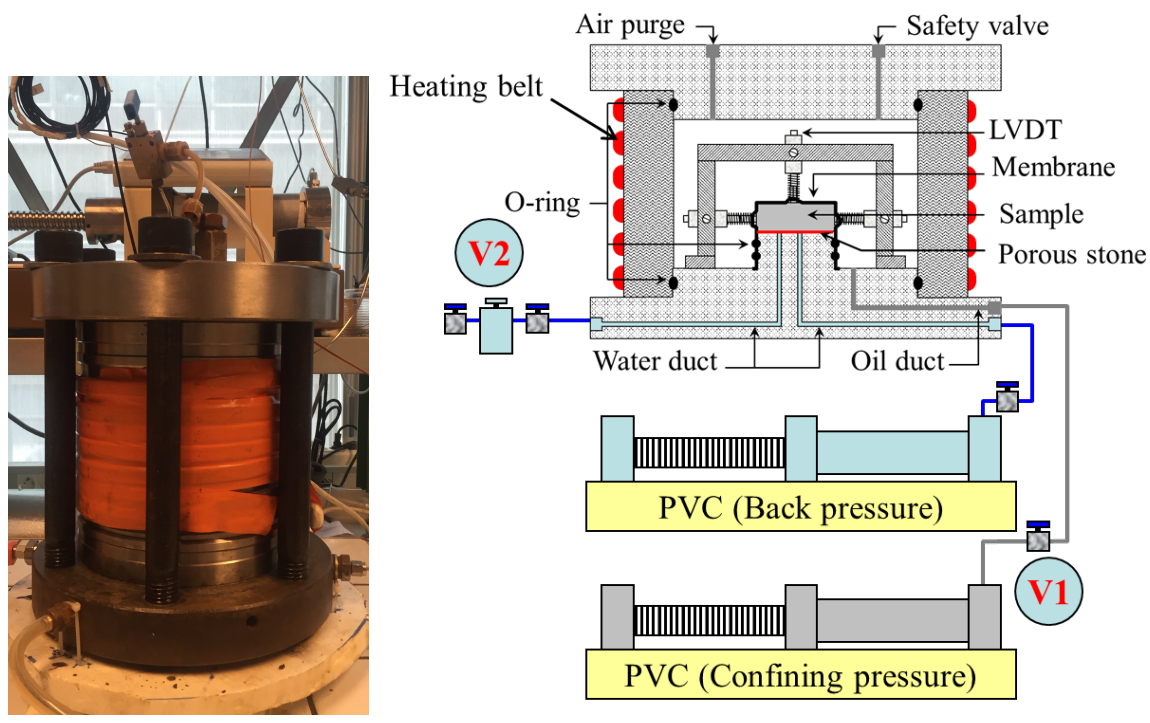

Figure 1. (a) Isotropic compression cell; (b) Overall system.

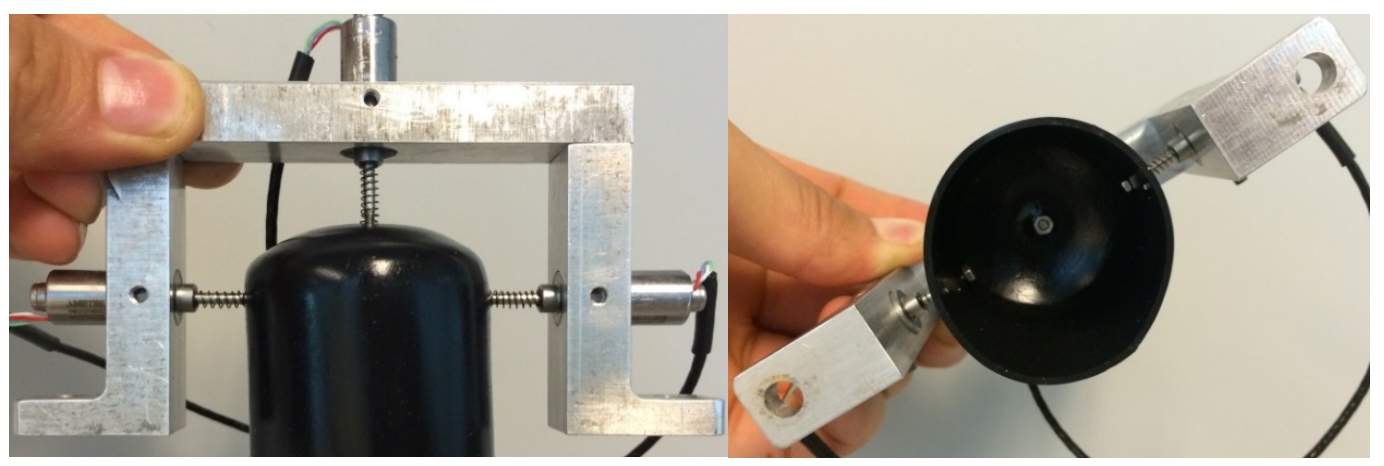

Figure 2. Displacement measurement system. 


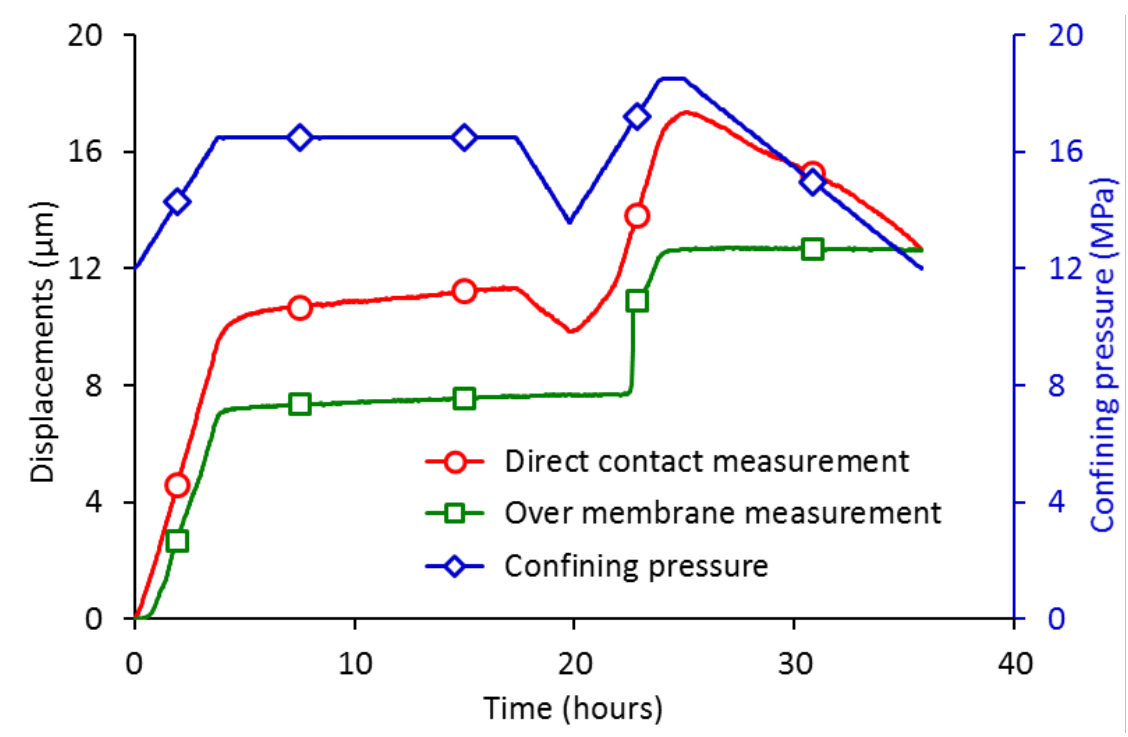

Figure 3. Accuracy of strain measurement in contact with the rock.
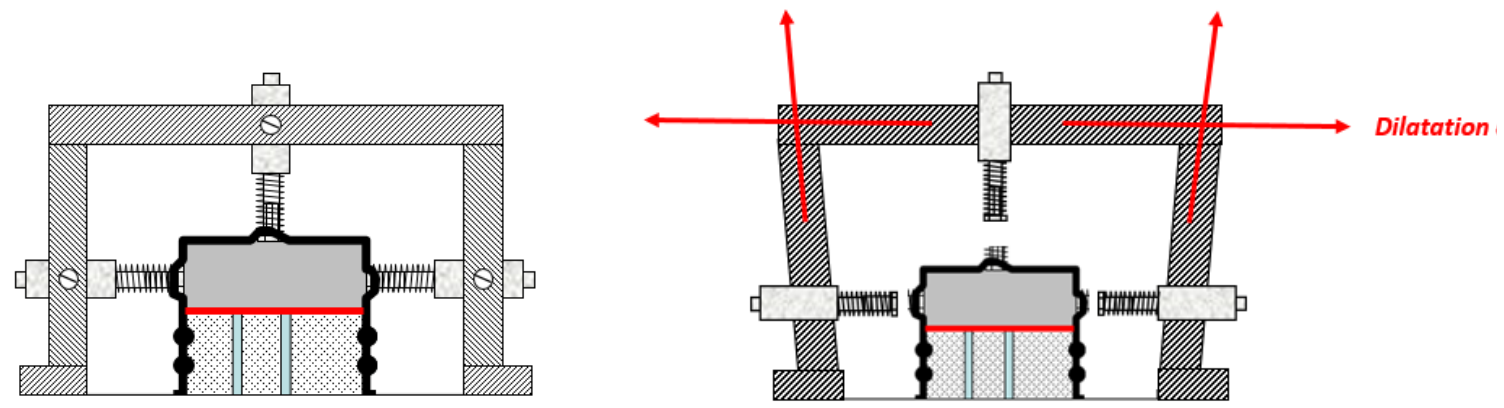

Figure 4. Thermal expansion of the LVDTs supporting system during heating; (a) intial state; (b) after heating.

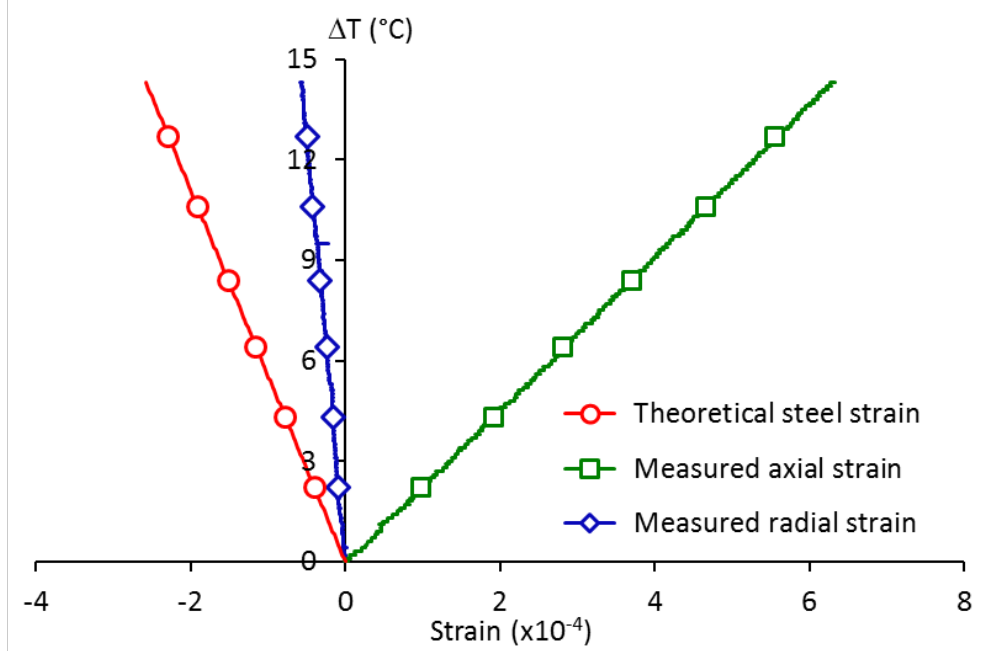

Figure 5. Measured axial and radial strain of a heated dummy steel sample. 


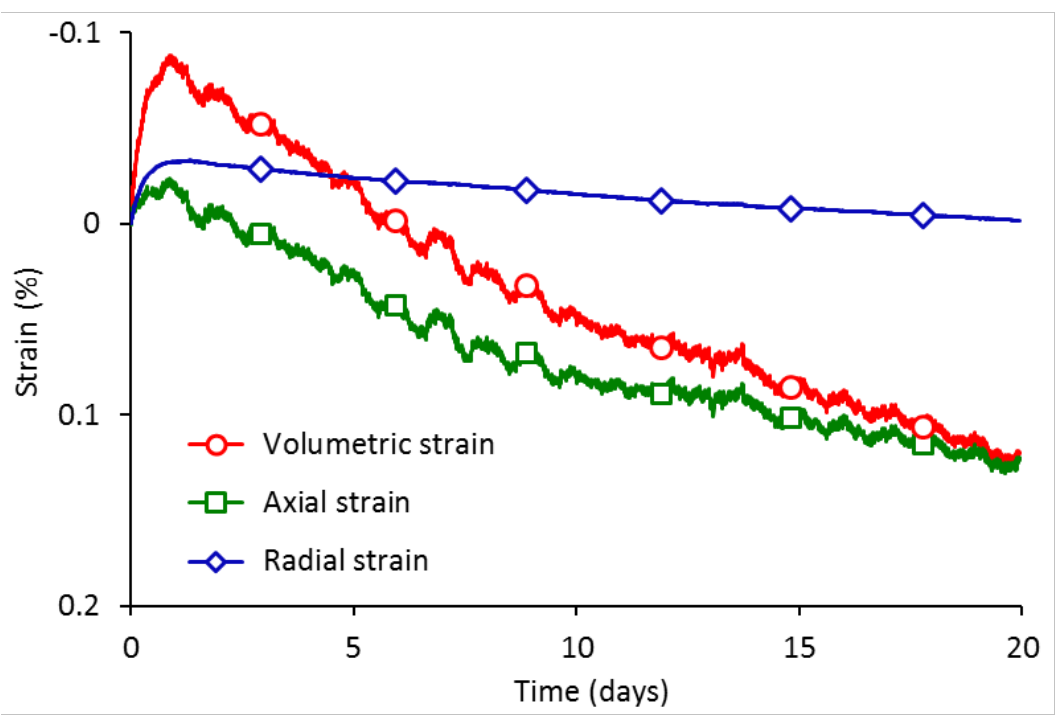

Figure 6. Measured strains during the resaturation phase under in-situ stress.
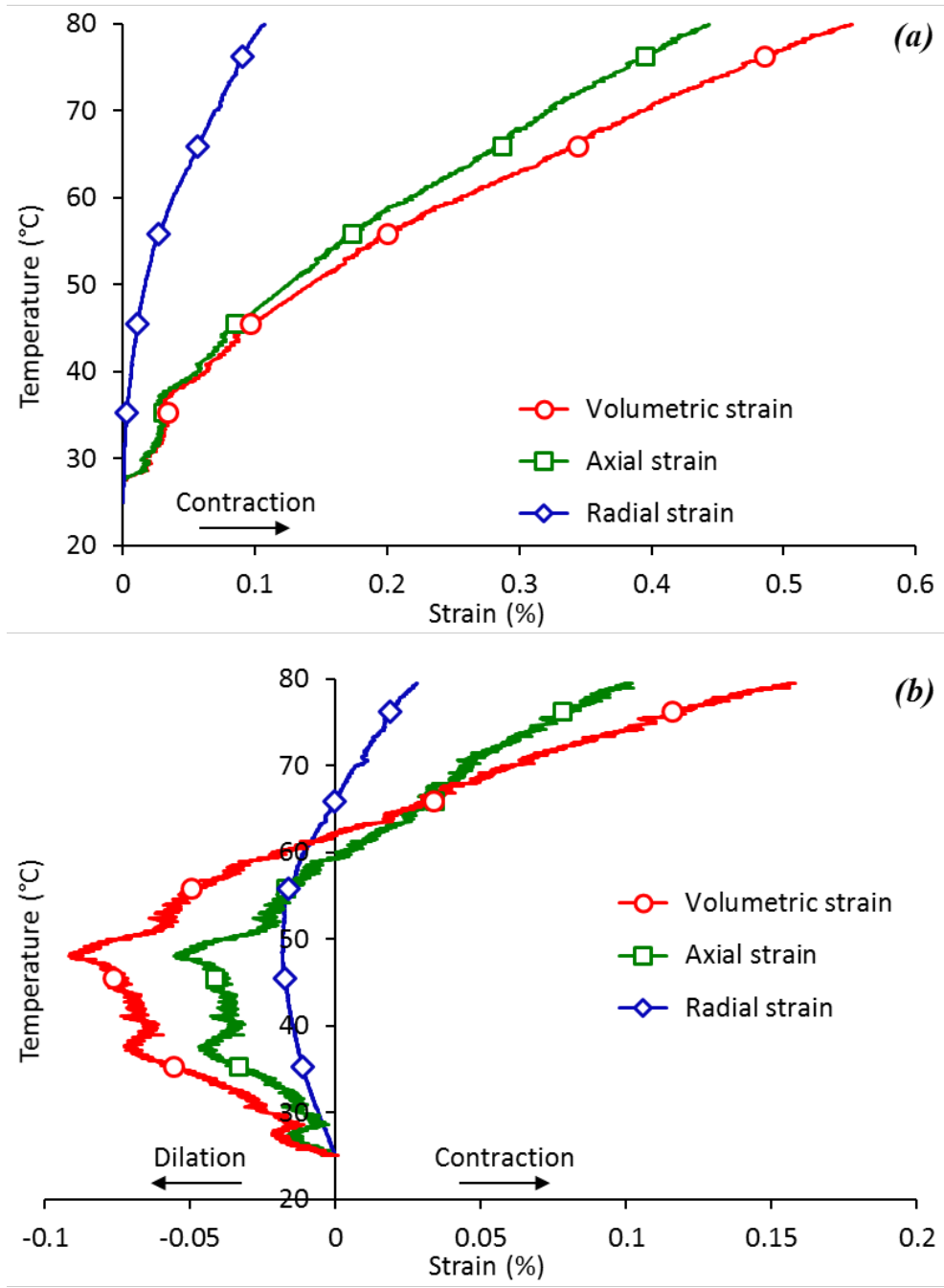

Figure 7. Measured (a) and corrected (b) strains in axial and radial LVDTs during heating. 

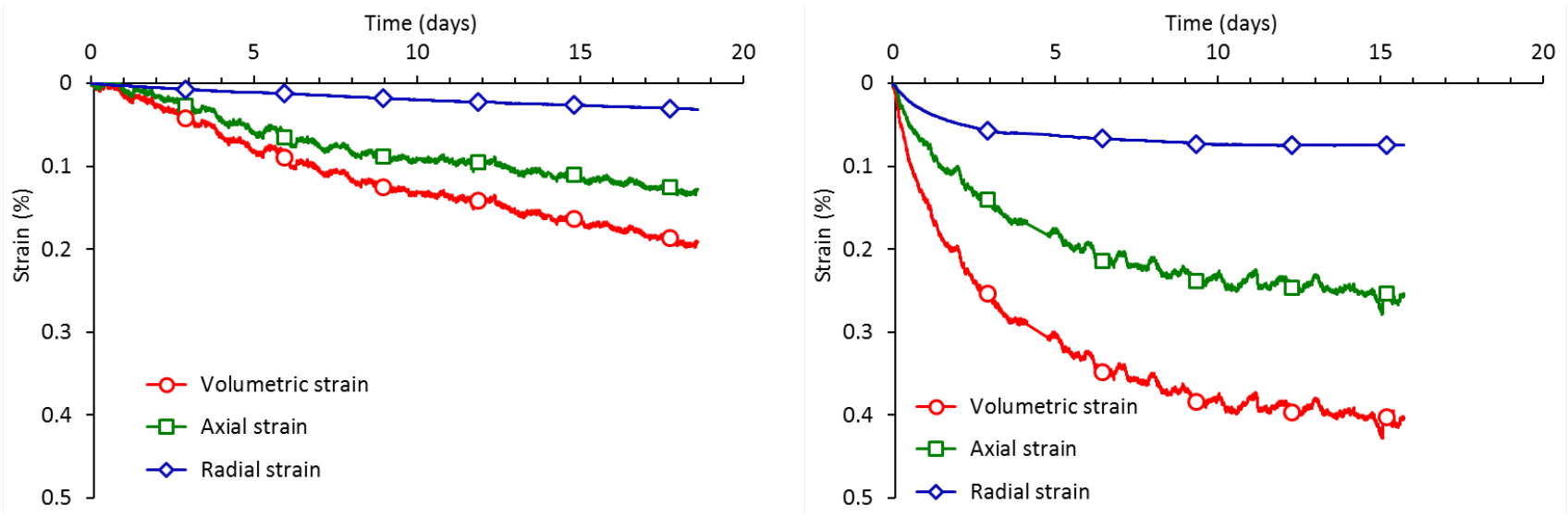

Figure 8. Creep strains: (a) $25^{\circ} \mathrm{C}$, (b) $80^{\circ} \mathrm{C}$.

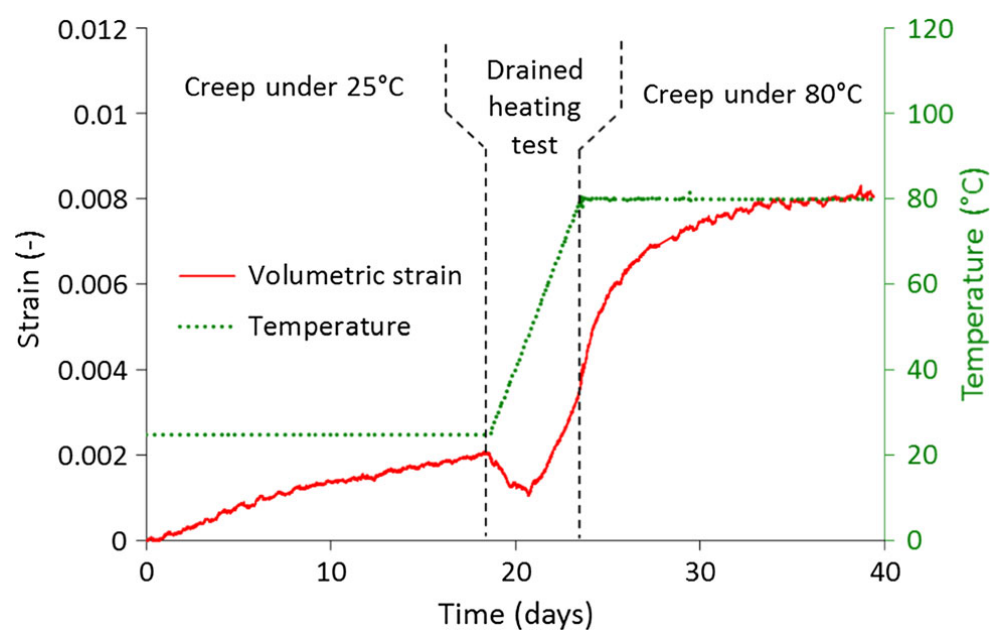

Figure 9. Volume changes monitored all along the test.

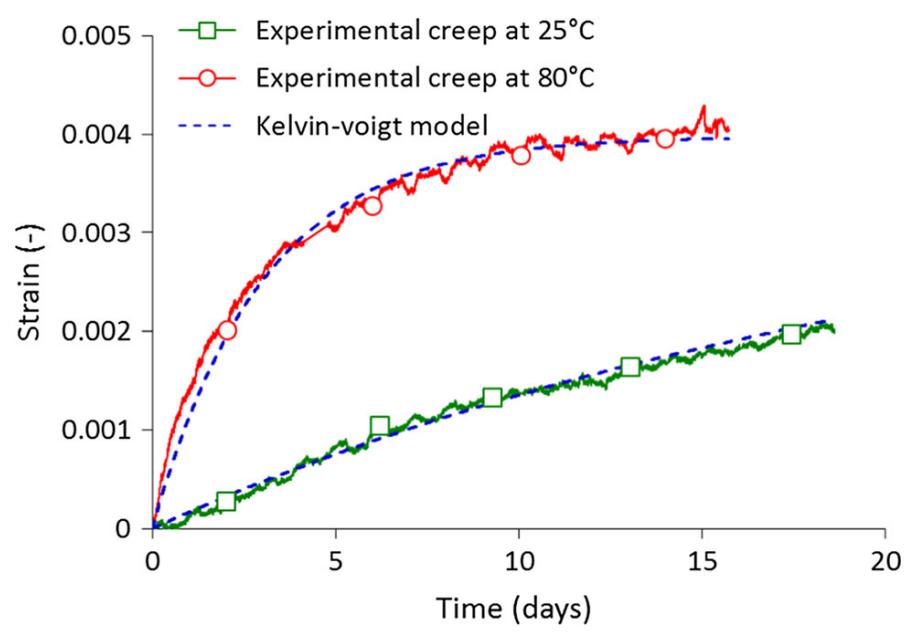

Figure 10. Measured and modelled creep strain at $25^{\circ} \mathrm{C}$ and $80^{\circ} \mathrm{C}$ 


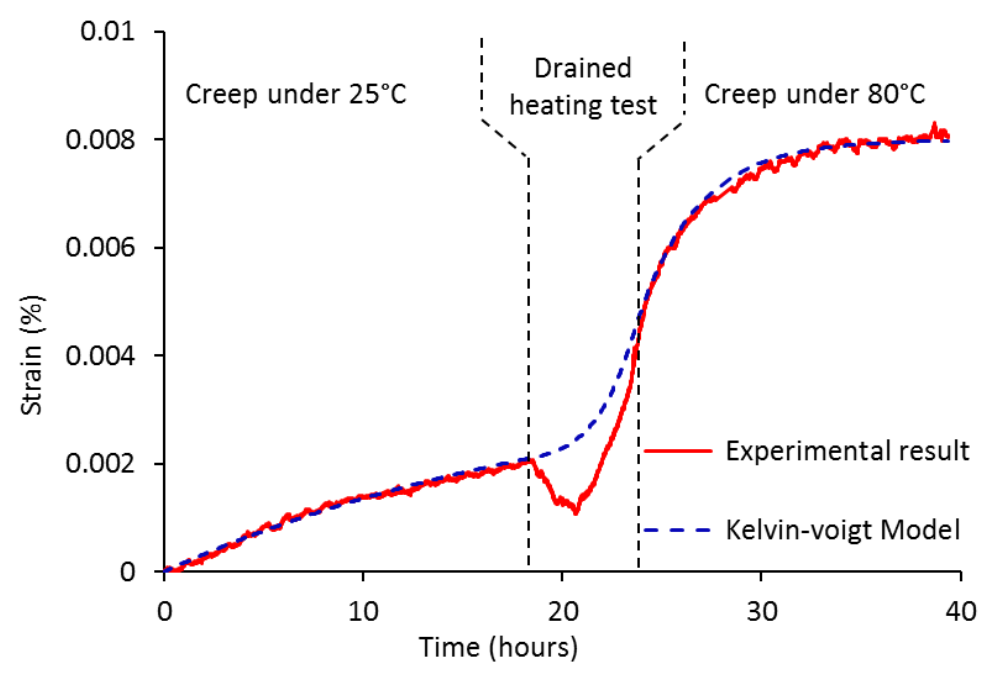

Figure 11. Overall measured strain and vs Kelvin-Voigt estimated creeping strain.

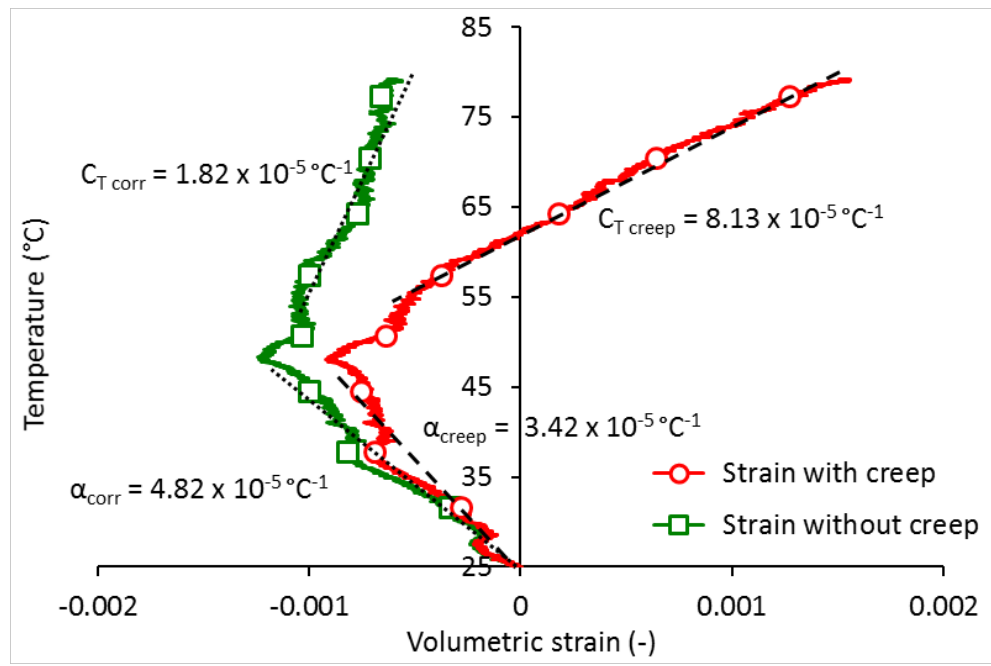

Figure 12. Comparison of the thermal volume changes with and without creep.

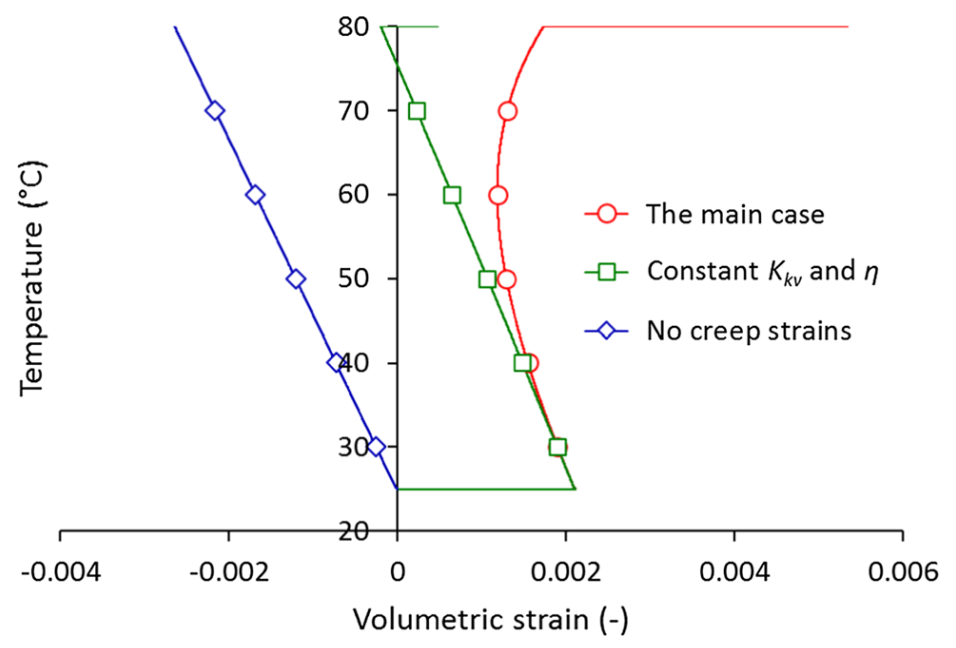

Figure 13. Simulation of volumetric strains during heating test. 


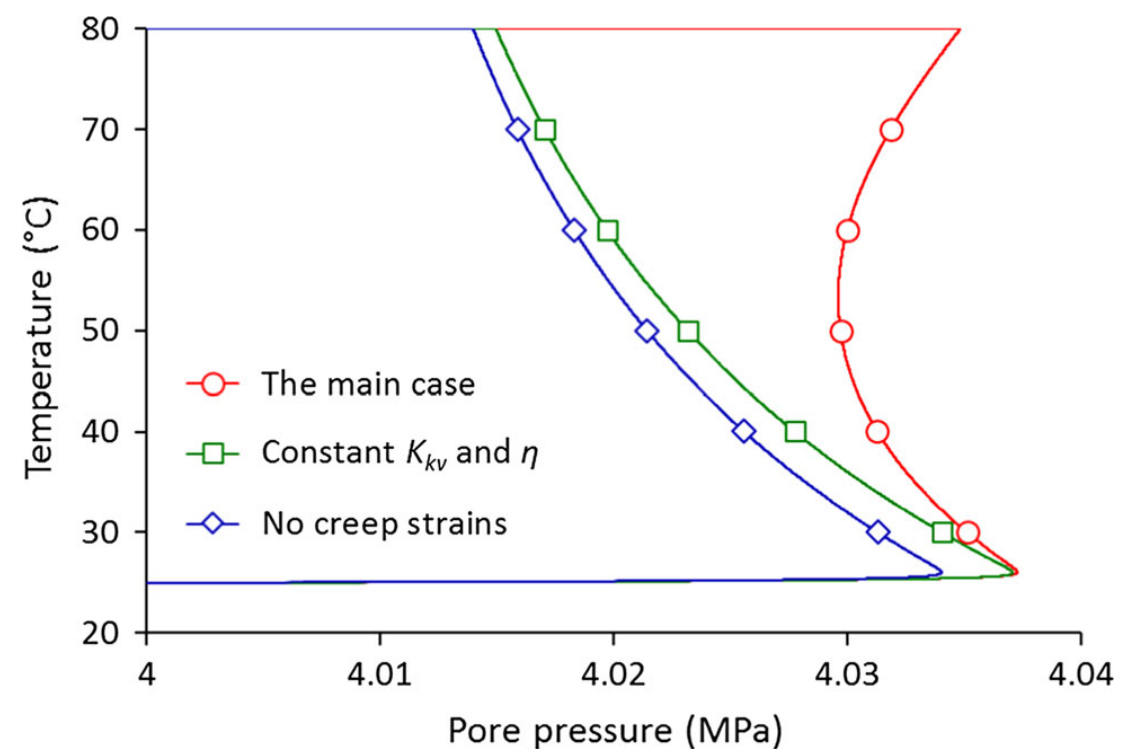

Figure 14. Simulation of pore pressure evolution during heating test. 


\section{Tables}

Table 1. Initial characteristics of the studied specimen EST51338.

\begin{tabular}{cccccccc}
\hline ID sample & $w(\%)$ & $\rho\left(\mathrm{g} / \mathrm{cm}^{3}\right)$ & $\rho_{d}\left(\mathrm{~g} / \mathrm{cm}^{3}\right)$ & $e$ & $S_{r}(\%)$ & $\phi(\%)$ & Suction $(\mathrm{MPa})$ \\
\hline EST51338 & 6.0 & 2.41 & 2.27 & 0.190 & 87.2 & 16 & 36.2 \\
\hline
\end{tabular}

Table 2. Parameters of the Kelvin-Voigt model.

\begin{tabular}{|c|c|c|}
\hline Temperature $\left({ }^{\circ} \mathrm{C}\right)$ & $K(\mathrm{MPa})$ & $\eta(\mathrm{MPa} . \mathrm{min})$ \\
\hline 25 & 3500 & $5.0 \times 10^{7}$ \\
\hline 80 & 1000 & $0.4 \times 10^{7}$ \\
\hline
\end{tabular}

Table 3. Material parameters used in the simulation.

\begin{tabular}{llllllll}
\hline Parameter & $K_{\mathrm{d}}(\mathrm{MPa})$ & $K_{\mathrm{s}}=K_{\phi}(\mathrm{MPa})$ & $b(-)$ & $\Lambda\left(\mathrm{MPa} /{ }^{\circ} \mathrm{C}\right)$ & $\phi_{0}(-)$ & $k\left(\mathrm{~m}^{2}\right)$ & $\alpha_{\mathrm{d}}\left(1 /{ }^{\circ} \mathrm{C}\right)$ \\
\hline Value & 2100 & 21.700 & 0.9 & 0.15 & 0.15 & $10^{-21}$ & $4.8 \times 10^{-5}$ \\
\hline
\end{tabular}

Table 4. Thermal expansion coefficients of the main minerals of the COx.

\begin{tabular}{|l|l|}
\hline Mineral & Thermal expansion coefficient $\alpha_{S}\left({ }^{\circ} \mathrm{C}^{-1}\right)$ \\
\hline Clay $(45 \%)$ & $3.4 \times 10^{-5}($ McTigue, 1986) \\
\hline Quartz $(23 \%)$ & $3.3 \times 10^{-5}($ Palciauskas and Domenico, 1982) \\
\hline Calcite $(28 \%)$ & $1.4 \times 10^{-5}($ Fei, 1995) \\
\hline Feldspars (4\%) & $1.1 \times 10^{-5}($ Fei, 1995) \\
\hline Water & $27 \times 10^{-5}($ Spang, 2002) \\
\hline
\end{tabular}

